stellt das Umweltprogramm der Bundesregierung [7] fest, daß ein einheitlicher Gütezustand der Gewässer im Hinblick auf die Bedürfnisse des Allgemeinwohles zu erreichen sei. „Die Merkmale werden der zweitbesten Gewässergüteklasse entsprechen müssen." Dieser Veröffentlichung ist eine Gewässergütekarte aus dem Jahre 1970 beigefügt.

Die Länderarbeitsgemeinschaft Wasser (LAWA) hat 1976 den Gewässergütezustand des Jahres 1975 für die wesentlichen Gewässer der Bundesrepublik Deutschland veröffentlicht [10]. Sie bedient sich hierbei wie auch die zuvor genannte Publikation des Saprobien-Systems.

Im Umweltgutachten 1978 [6] wird festgestellt, daß bei der Ausfüllung der wasserrechtlichen Rahmengesetze das Ziel einer ökologisch und ökonomisch effizienten ggf. auch regional abgestuften Gewässersanierung Vorrang haben sollte. Die Untersuchung des Ökosystems im Gewässer ist also ein Teilaspekt der Gewässerbeurteilung.

1. Bick, H.: Hydrobiologica 31, 17 (1968)

2. Bick, H.: Fasc. 1, 7, 8, 9 WHO/VBC/69.21, 69.136, 69.139, 69.143, Geneva 1969

\section{The Abstract Hypercycle}

\author{
M. Eigen and P. Schuster
}

Naturwissenschaften 65, 11 (1978)

E.O. Siré (Institut für Physikalische Chemie, Universität Frankfurt am Main) kindly pointed out, that there is an error in the caption of Fig. 17. It deals with a question which is not related to the evolutionary problems discussed in this paper but for the sake of completeness should be corrected:

The solution curves of the differential equations

$\dot{x}=\exp (1-x)$

and

$\dot{x}=x^{p},-\infty<p<1$

with $x(0)=1$ and $\dot{x}(0)=1$ as initial conditions, namely
3. Bock, K.J., Scheubel, J.B., Schöberl, P.: Lichtbogen 184, 7 (1977)

4. Buck, H.: Münch. Beitr. Abwasser-, Fischerei-, Flußbiol. 19, 14 (1971)

5. Bundesminister des Innern: Bundestagsdrucksache VI/2170. Bonn 1971

6. Bundesminister des Innern: Umweltbrief 17 (1978)

7. Deutscher Bundestag: Bundestagsdrucksache VI/2710. Bonn 1971

8. Fachgruppe Wasserchemie in der Gesellschaft Deutscher Chemiker: Deutsche Einheitsverfahren zur Wasser-, Abwasser- und Schlammuntersuchung. Weinheim: Verlag Chemie 1960

9. Institut für Wasserwirtschaft Berlin: Ausgewählte Methoden der Wasseruntersuchung, Bd. II. Jena 1970

10. Länderarbeitsgemeinschaft Wasser: Die Gewässergütekarte der Bundesrepublik Deutschland. Mainz 1976

11. Liebmann, H. : Handbuch der Frischwasser- und Abwasserbiologie, Bd. I, II. München 1960/1962

12. Liebmann, H.: Münch. Beitr. Abwasser-, Fischerei-, Flußbiol. $6(1959)$

13. Liebmann, H.: ibid. 15 (1969)

14. Mauch, E.: Cour. Forsch. Inst. Senckenberg 21, Teil $1-5$ (1976)

15. Sladecek, V.: Erg. Limnol. H. 7 (1973)

Eingegangen am 29. November 1978

$x=1+\ln (t+1)$

and

$x_{p}=[1+(1-p) t]^{1 / 1-p}$

respectively, have two crossing points along the positive time axis $(0 \leqq t<\infty)$ if $p<-1$ (one at $t=0, x=1$ and the second at some value $t>0, x>1$ ). Hence there is no "curve 4" separating a region of growth to finite values ("A") from the region of growth to infinity ("B"). The conclusions for large enough $t$ as well as all statements made in the text remain unaffected. 